\title{
La huida de la Sirena. Una narrativa del desastre de la desecación y el despojo en los pueblos ribereños al noreste de la Ciudad de México*
}

The escape of la Sirena. A narrative of the disaster of desiccation and dispossession in the shore towns of eastern Mexico City

\section{REsUMEN}

En este artículo, analizo los sentidos locales del proceso histórico de desecación del último de los lagos sobre los que se fundó la Ciudad de México hace más de setecientos años: el lago de Texcoco. Destaco una narrativa local sobre la huida de una Sirena, como un registro de significado que da sentido a la desaparición del lago en términos de una pérdida dolorosa y de despojo para la población de la orilla nororiental del lago. Asimismo, esta narrativa sugiere pensar la desecación histórica de la cuenca de México como un desastre progresivo y vigente. De tal manera, el objetivo que persigue este escrito es explorar los vínculos que guardan los proyectos de desarrollo, los desastres lentos y las formas múltiples del despojo. Muestro que el despojo se ha materializado y significado de formas particulares y desiguales en distintos periodos de tiempo. Destaco tres momentos para indagar sobre las formas en que se coproducen, junto al desastre, distintas e inclusive contradictorias modalidades de despojo, que van más allá del arrebato o cercamiento de los bienes colectivos.
Ariana Mendoza Fragoso

Universidad Autónoma de

México y CIESAS, México.

\arianamendoza@filos.unam.mx

(1D) ORCID: 0000-0002-6354-5433

$\checkmark$ Google Scholar

*Los datos etnográficos y la discusión vertida en este texto hacen parte de los resultados de mi investigación doctoral realizada en el Centro de Investigación y Estudios Superiores en Antropología Social, Ciudad de México, entre los años 2017 2021, con apoyo económico del Consejo Nacional de Ciencia y Tecnología de México. Agradezco a Alejandro Camargo, editor invitado en este Dossier, por su lectura atenta y sugerente a un primer borrador de este texto y a los evaluadores ciegos del artículo que contribuyeron también con valiosos comentarios. Finalmente, agradezco a todas las personas de los pueblos a la orilla del lago de Texcoco que me acogieron y compartieron su vida conmigo con gran generosidad. Los posibles errores u omisiones son de mi entera responsabilidad. 
Palabras clave: desecación, desastre, desarrollo, agua, despojo, urbanismo

\begin{abstract}
In this article, I analyze the local meanings of the historical drying out process of the last of the lakes on which Mexico City was founded more than seven hundred years ago: Lake Texcoco. I highlight a local narrative about the escape of a mermaid, as a register of meaning for the population of the northeast shore of the lake, that gives sense to the disappearance of the lake in terms of a painful loss and dispossession. Likewise, this narrative suggests thinking of the historical drying out of the basin of Mexico as a progressive and ongoing disaster. Thus, the objective pursued by this text is to explore the links between development projects, slow disasters and multiple forms of dispossession. I show that dispossession has materialized and signified in particular and unequal ways in different periods of time. I highlight three moments to inquire about the ways in which different and even contradictory forms of dispossession are co-produced, together with the disaster, and go beyond the seizure or enclosure of collective property.
\end{abstract}

Keywords: desiccation, disaster, development, water, dispossession, urbanism.

\title{
Introducción
}

a cuenca endorreica que dio origen al sistema de cinco lagos ${ }^{1}$ en donde hoy se despliega la Ciudad de México (CDMX) y su área metropolitana, con más de 21 millones de habitantes, ha atravesado por un largo proceso de desagüe (Figura 1). De aquel antiguo sistema de lagos, Texcoco fue el de más extensión, encontrándose en la parte más baja de la cuenca, además, se diferenciaba de los anteriores por sus cualidades salinas. Actualmente, este lago se encuentra ausente como cuerpo de agua homogéneo y permanente. Sin embargo, se hace presente en algunos cuerpos de agua artificiales que funcionan como parte de la infraestructura hidráulica de desagüe de la ciudad. También toma la forma de algunos charcos de agua e inundaciones que se crean sobre todo en 
época de lluvias. Asimismo, se materializa en las ondulaciones, agrietamientos, la fangosidad y la salinidad de los suelos cercanos a su lecho.

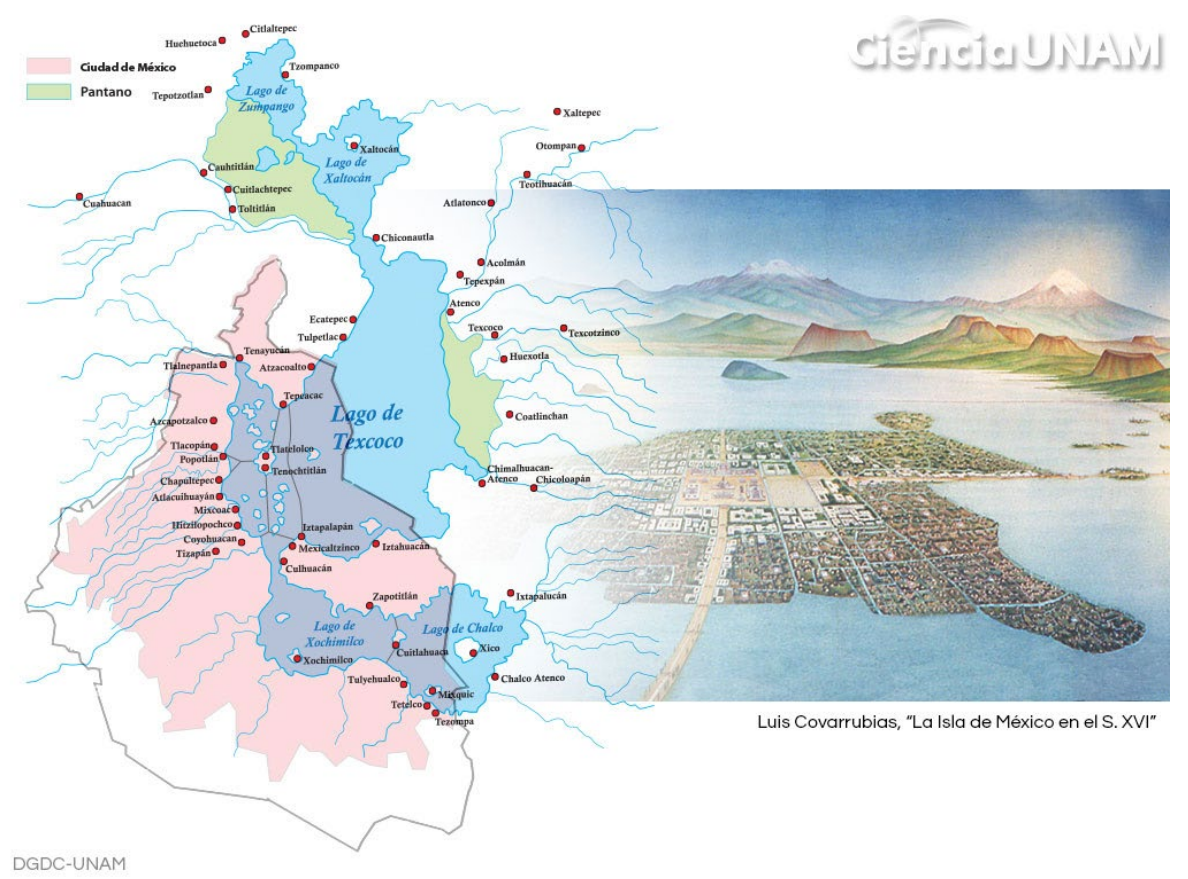

Figura 1. El sistema de lagos de la cuenca de México y los pueblos aledaños que circundaban a la Gran Tenochtitlan a principios del siglo XVI, sobre un mapa actual de los límites de la Ciudad de México.

Fuente: Soto Coloballes, N. (2019a).

Discursiva y simbólicamente, el lago cobra presencia no solo en la denominación como pueblos ribereños o costeros a la que responden los pueblos que se asentaron desde tiempos prehispánicos en su orilla noreste, sino inclusive en las imágenes que cuelgan en las paredes de muchas de las oficinas de las autoridades locales o en los murales de los auditorios comunitarios. También está presente en las narrativas locales sobre el pasado de estas poblaciones, como es el caso del mito de La sirena, un personaje mítico que tiene presencia en otras tantas poblaciones con origen lacustre en los valles centrales de México (Albores, 1995).

Durante mi estancia de trabajo de campo, entre los años 2018-2019, en las poblaciones de la orilla noreste del lago, conocidas regionalmente como "pueblos de la Costa Chica", indagué entre los pobladores sobre las causas de la desecación del cuerpo de agua al que deben su apelativo. Las ancianas y ancianos recurrieron frecuentemente a este personaje femenino para explicarme el suceso: 
[...] Pues casi de anochecer a amanecer se secó porque se fue la Sirena. Tenía su lugar ahí en los ahuehuetes ${ }^{2}$, salía ahí en la taza de la parcela del difunto Sabino Díaz, por esos lados [...] ahí en esa taza se bañaba ella, había mucha agua ahí [...] cuando se secó el lago, se fue para el mar y cuando tenía como unos diez años de seco el lago, encontraron un papel diciendo que, bueno, que tenía que llenar su lago de vuelta, que no se tenía que desaparecer. Pero, como el diluvio que venga, todo va a ser normalidad como antes estaba, México va a ser laguna de vuelta. Así lo encontraron el papel. (Entrevista a J.G, 84 años, San Miguel Tocuila, Texcoco, 28-01-19)

En este artículo doy centralidad a este mito porque lo considero de gran potencial epistémico para comprender un proceso violento de transformación socio ambiental, desde sentidos y significados subalternos. Narrativas hegemónicas sobre el desagüe de la cuenca -a las que referiré más adelante- proclaman a éste como una victoria de la modernización sobre el pasado pantanoso de una nación en ciernes al que nadie quisiera volver. En cambio, esta narrativa presenta a la desecación como una dolorosa experiencia de pérdida y, al mismo tiempo, da cabida a la añoranza de aquel pasado lacustre, como una especie de contestación al proyecto de modernidad urbana.

Desde esta perspectiva, el mito de la Sirena va más allá de la escala local y de la misma cuenca de México. Mirando más a profundidad, se enmarca también como un registro de significado acerca del proyecto civilizatorio global de modernización y desarrollo en clave de crecimiento urbano, el cual, en las últimas décadas, distintos actores han comenzado a vincular más explícitamente con los procesos de crisis climática y deterioro ambiental mundial, por ejemplo, en el debate que gira en torno al concepto de Antropoceno.

En este contexto, el mito de la Sirena es un indicio espléndido para ubicar los sentidos y las experiencias concretas y subalternas sobre dicha crisis y su vínculo con el proyecto global de modernización. Este mito se ha materializado entre los pueblos costeros, particularmente como un proceso de pérdida de los espacios de agua, los que antiguamente posibilitaron el sostenimiento de esta población y además dieron sentido a sus identidades colectivas. Esta narrativa registra, entonces, no sólo un

Taxodium mucronatum. Conífera predominante en los Valles Centrales de México, de grandes dimensiones y de vida longeva que se desarrolla en lugares con abundancia de agua. De ahí su nombre en náhuatl: ahuehuetl, que al castellano significa "viejo del agua". 
proceso concreto y percibido de transformación socio ambiental, sino también de dimensiones subjetivas.

De tal manera, frente a la normalización del desagüe de la cuenca por gran parte de quienes la habitan y administran en nuestros días, sugiero considerar la narrativa de la Sirena como una narrativa que impugna y explicita el desagüe de la cuenca, en la medida que lo presenta como un proceso de destrucción y pérdida latente, es decir, como un desastre. Por otro lado, las trayectorias de vida de los pobladores de mayor edad, dan cuenta de que la experiencia de vivir esta pérdida se ha soportado, a su vez, como múltiples y contradictorias formas de despojo. Este despojo no sólo tiene que ver con el despojo de bienes, sino también con otras formas más subjetivas y prolongadas en el tiempo de experimentar las afectaciones de los desastres.

En ese sentido, el objetivo de este escrito es problematizar las articulaciones entre los proyectos de desarrollo, los desastres y las formas de despojo que han sido resultado de, y también van posibilitando, los desastres mismos. Los datos y argumentos que presento en función de dicho objetivo están fundamentados en el trabajo de campo etnográfico que realicé por alrededor de un año y medio en la región de la Zona Metropolitana del Valle de México (ZMVM), conocida como Texcoco, a unos 30 kilómetros al nororiente del centro de la CDMX. Particularmente, recurro a las entrevistas que realice a pobladores y autoridades locales, así como a mis notas de campo formuladas durante mi observación participante en seis poblaciones localizadas en la orilla noreste del lecho del lago, correspondientes a los municipios de Texcoco y Atenco, en el Estado de México (Figura 2). 


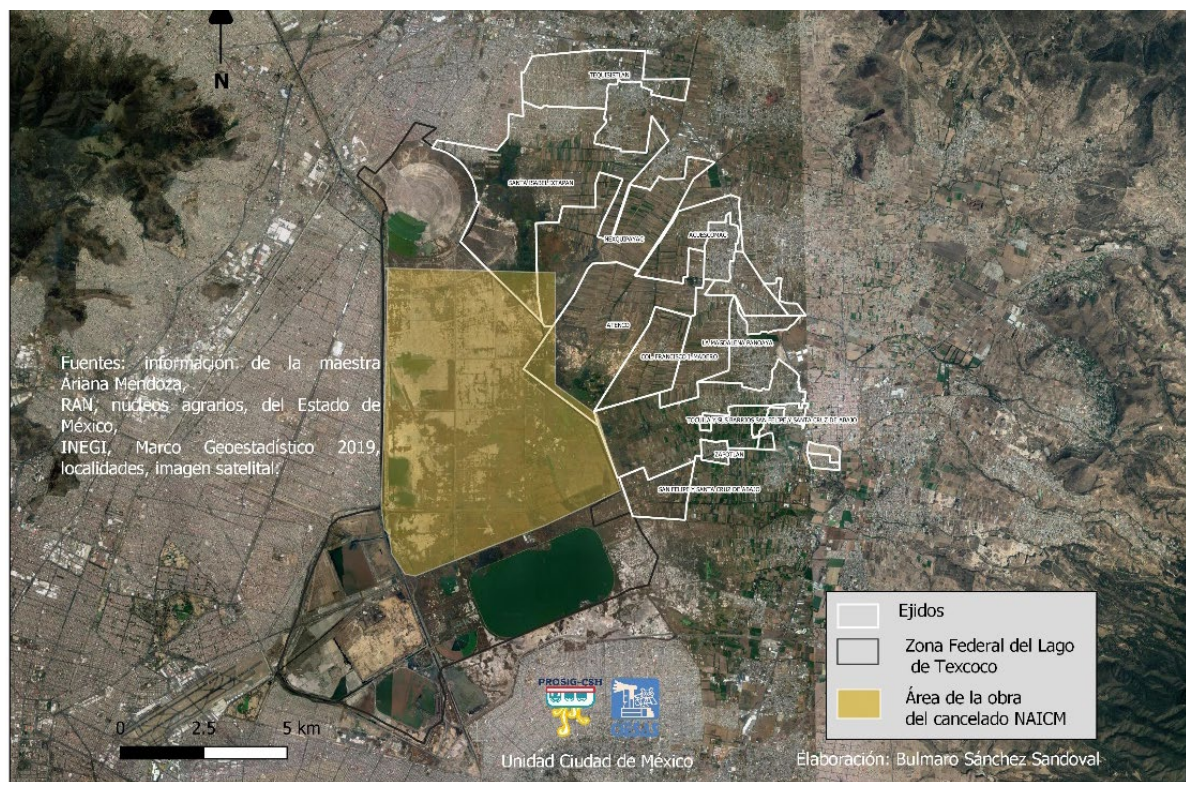

Figura 2. Los pueblos de la Costa Chica del Lago de Texcoco,

al nororiente de la Ciudad de México.

Fuente: información de campo de Ariana Mendoza, RAN;

núcleos agrarios del Estado de México, INEGI, Marco

Geoestadístico 2019, localidades, imagen satelital.

Contrario a la ideología hegemónica del progreso, que sugiere que es justamente la modernización la que nos debería de colocar en escenarios menos vulnerables en la medida en que avanzamos en la escala del desarrollo. Valiéndome de las particularidades ecológicas y materiales de la cuenca de México, así como de la experiencia de su desecación desde un lugar concreto, mi argumento central es que los proyectos de modernización o desarrollo urbano muchas veces son generadores o amplificadores de desastres. Propongo que la narrativa de la modernización, que más recientemente ánima los discursos de la resiliencia urbana, oculta cómo, tanto el desastre como el desarrollo, son ambos procesos relacionales al despojo.

Es así que, con este artículo, busco aportar a tres discusiones más amplias que ya han comenzado con anterioridad otras autoras y autores. En primer lugar, a la problematización de las relaciones entre desastre y despojo, considerando a éste último no sólo como efecto, sino también como generador de desastres. En segundo lugar, y dado que me interesa resaltar la perspectiva de larga duración del desastre de la desecación de 
la cuenca de México, quiero abonar a la lectura de los procesos graduales y las formas sutiles, menos espectaculares pero igualmente violentas, de los desastres, en relación con lo que ya otras y otros autores han trabajado, por ejemplo, bajo el concepto de slow violence (Nixón, 2011). En tercer lugar, el análisis aquí expuesto es también una contribución a las discusiones más recientes sobre el despojo, las cuales proclaman otros entendimientos de este concepto más allá de la acumulación por despojo del geógrafo David Harvey (2004). Dialogo entonces con autoras como Navarro (2015) y Federici (2010), quienes, al dar centralidad al ámbito de la reproducción y no solo al de la producción de capital, entienden el despojo en relación con las subjetividades políticas. También retomo de autoras como Hart (2016), Li (2010), Ojeda (2016), Butler y Athanasiou (2017), su llamado a inyectar al concepto de comprensiones concretas desde las historias, las memorias y los significados específicos del despojo.

Organizo el artículo en dos grandes secciones. La primera tiene la finalidad de contextualizar, tanto teórica como empíricamente, a los y las lectoras. Sin pretensión de ser una revisión exhaustiva, expongo algunas notas sobre la historia ambiental, específicamente del agua, de la cuenca de México. La finalidad es brindar un panorama general del binomio inundación-desecación que configura la paradójica situación actual de esta urbe. Ahí planteo pensar ambos procesos, para el caso que atañe, como desastres potenciales y relacionales entre sí. Posteriormente, enmarco teóricamente mis argumentos a cerca de establecer encadenamientos entre desastres, desarrollo y despojos.

En la segunda parte del artículo examino, a partir de la historia socio ambiental de los pueblos de la Costa Chica texcocana, los particulares vínculos que adquieren en este lugar el desastre, el desarrollo y los despojos. Organizo esta sección de acuerdo a tres épocas en las que se impulsaron distintos proyectos modernizadores en la región: el reparto agrario, durante el México posrevolucionario; la industrialización del norte de la Ciudad de México, bajo el modelo de sustitución de importaciones y; por último, la construcción de un nuevo aeropuerto internacional en el marco de las políticas neoliberales. Doy cuenta de estos tres momentos del desarrollo teniendo como correlato el desastre de la desecación de larga data y en donde el despojo cobra distintas modalidades y efectos múltiples, inclusive contradictorios. De ahí que, parafraseando a Gillian Hart (2016), en este texto desnaturalizo el despojo para, de paso, contribuir a la desnaturalización del desecamiento de la cuenca de México al replantearlo como un desastre del desarrollo (Oliver Smith, 2009 y 2010). 


\section{La metrópoli del Valle de México y su emergencia del agua}

Un reportaje de Kimelman (2017) en el New York Times titulado "Ciudad de México, al borde de una crisis por el agua", señalaba hace cuatro años que el cambio climático amenaza con llevar a la megalópolis mexicana hacia un colapso ambiental sin precedentes. Lo que llama la atención es que, a lo largo de la historia de la ciudad, otras veces ya se ha hablado en términos catastróficos, por ejemplo, en la gran inundación que sucedió en el año de 1951, lo que condujo a la construcción de una gran infraestructura de drenaje profundo. Al parecer, la narrativa de la catástrofe y el colapso, ha motivado o justificado, principalmente, la construcción de cada vez más infraestructuras.

Por otro lado, las mismas palabras son también frecuentemente usadas en la cotidianidad de quienes habitan la metrópoli. Por ejemplo, se habla de situaciones críticas cuando han pasado más de tres días y hasta semanas sin recibir alguna gota de agua en las tuberías de los hogares más vulnerables. Se habla de vialidades y el sistema de transporte público colapsado cuando la lluvia es tanta que los drenajes son insuficientes y en las zonas más bajas y vulnerables se llegan a inundar las viviendas. Es un hecho que ciertas poblaciones experimentan, unas más que otras, una crisis en términos hídricos, ya sea por la falta del líquido o por su abundancia a manera de desastre.

Dicha crisis se resume en una paradoja. La ciudad drena una gran cantidad de aguas residuales y de lluvia a través de una enmarañada red de infraestructuras de desagüe para evitar que se inunde. Al mismo tiempo, es necesaria otra gran cantidad de infraestructura para exportar agua mediante trasvases de cuencas vecinas, y también para extraer agua del acuífero cada vez a mayor profundidad. Y es que esta megalópolis tiene como particularidad su emergencia del agua; no sólo en el sentido de la crisis hídrica que se vive, sino también por tener su origen en el agua. Me refiero a que el agua es fundante y al mismo tiempo amenazante, pero siempre constitutiva de la ciudad. El sistema de lagos del que emergió la ciudad se ha ido transformando para hacerlo habitable a los distintos modelos de desarrollo de cada época. 
A lo largo de casi siete siglos se han construido distintas infraestructuras ${ }^{3}$, cada una con el claro objetivo de evitar que la ciudad se inunde y que ésta pueda continuar con su crecimiento económico, con la concentración del poder político a nivel nacional y, en las últimas tres décadas, con la posibilidad de convertirse en una ciudad de "competencia mundial". En su respectiva época, cada una de estas infraestructuras se ha planteado, por parte de los agentes del Estado, como la solución definitiva a los problemas de inundación y hundimiento de la ciudad. Sucedida una tras otra, los esfuerzos siempre han resultado insuficientes porque, entre otras cosas, los proyectos de desarrollo como construcciones inmobiliarias, parques industriales, logística, así como nuevas vialidades y nodos de transporte, siguen proliferando en medio de una ciudad ya desbordada desde hace décadas.

Siguiendo a Swyngedouw (1997, p. 311), podríamos decir que estamos ante una "urbanización del agua", pues el proceso histórico de urbanización y modernización de la cuenca se ha basado, fundamentalmente, en la conquista, dominación y domesticación de ésta. Procesos que son vigentes y suceden cotidianamente a lo largo y ancho de toda la ZMVM. Hoy día se requiere aún de una gran cantidad de trabajo humano, tecnologías y capital público y privado para gestionar las aguas que entran y salen de la metrópoli.

Sin embargo, tal pareciera que junto a la normalización de este proceso hay una positividad reiterada y depositada en el desagüe de la cuenca entre los discursos de los agentes del capital y del Estado vinculados al tema del agua y de la planeación urbana. En común con la narrativa de la Sirena, el mito fundacional de la antigua ciudad de Tenochtitlan también hace referencia al mismo lago. Aunque en esta historia interviene otro personaje: un águila parada sobre un nopal, que fuera la señal que mostraría el lugar indicado donde debía de edificarse la ciudad que albergaría a un gran poderío. Aquella escena mítica ha quedado enmarcada, reiterada una y otra vez, como el Escudo Nacional mexicano. De tal manera, sobre la desecación de la cuenca, hay también una narrativa oficial, nacionalista y fundacional que destaca con orgullo la construcción de una majestuosa ciudad sobre el mismo lago que reclama la Sirena de los pueblos ribereños de Texcoco.

La infraestructura de drenaje de la Ciudad de México y su área metropolitana está hoy día unida a cuatro sistemas: el Tajo de Nochistongo, inaugurado en 1789, y el Gran Canal del Desagüe, puesto en marcha en una primera fase en 1900. También está el drenaje profundo conformado por el Emisor Poniente, que data de 1962; el Emisor Central, inaugurado en 1975; y la más reciente obra inaugurada en 2019, el Tunel Emisor Oriente (Legorreta, 2006; Soto Coloballes, 2019b). 
A diferencia de la narrativa de la Sirena que da cuenta de una pérdida dolorosa, en esta narrativa nacionalista la pérdida del lago no es central; lo que es central es el orgullo de haber edificado el Estado-nación sobre él. En ese sentido, de cara a la modernización y enmarcadas en un discurso a favor de incrementar la resiliencia de la ciudad -que naturalmente tiende a inundarse-, los agentes del Estado apelan constantemente al mito fundacional para legitimar las grandes infraestructuras que hacen posible la moderna ciudad; refiriéndose a la majestuosidad de las obras y la perspicacia de la ingeniería mexicana como una herencia de las antiguas civilizaciones.

Esta narrativa hegemónica de la desecación alimenta una especie de fetichismo de la ciudad sobre el lago. Un discurso que resalta la positividad del desecamiento en términos de progreso, de tal manera que relega la presencia del agua a un pasado superado e invisibilizando, así, la destrucción que este proceso ha dejado y sigue dejando a su paso. Tal es así que pocas veces se nombra al desagüe mismo, que acontece a diario, como desastre. Por el contrario, los discursos oficiales sobre los riesgos y vulnerabilidades de la ciudad se han nutrido más recientemente del discurso informado globalmente sobre la resiliencia. Destacando las formas en que la ciudad y su población han podido reponerse ante las circunstancias "naturales", como movimientos sísmicos, inundaciones y hundimientos, que, desde esta perspectiva, han condicionado casi de manera innata a la población de esta ciudad. En ese marco, los gobiernos más recientes de la ZMVM han basado sus planeaciones, e inclusive el gobierno de la CDMX ha sido galardonado por la ONU.

No obstante, la ideología de la resiliencia lleva implícita una ideología modernizadora y de mercado, pues destaca la innovación tecnológica y la construcción de infraestructuras sofisticadas como las formas idóneas para contrarrestar los riesgos. Estas acciones y planteamientos restan responsabilidades al Estado sobre su papel en la intensificación o respuesta ante los desastres y, al mismo tiempo, promueven la generación de más proyectos de modernización que implican, la mayoría de las veces, la construcción de más espacios urbanos e infraestructura (verde o inteligente).

La narrativa sobre la resiliencia de esta ciudad se basa, entonces, en una lectura unilineal, antropocéntrica y modernizadora de la historia socio ambiental de la urbe. En palabras más claras, esta narrativa destaca el poder de las fuerzas tecnológicas, estatales y del capital (y algunas veces de la organización comunitaria) que han podido continuar con el desarrollo de la metrópoli pese a sus particulares vulnerabilidades y 
en el contexto también de las narrativas globales del colapso y la crisis ambiental. Desde esta perspectiva, al parecer, el mismo hecho de que la ciudad haya emergido sobre un ecosistema de lagos, del cual quedan tan solo algunos reductos, no sugiere en sí mismo destrucción o alerta, sino todo lo contrario, el orgullo de haber erguido la ciudad sobre un pasado pantanoso, el cual se ha perdido de vista de cara a las expectativas de un futuro moderno, seco y tecnologizado en donde sea viable seguir acumulando capital.

Por su parte, en la Costa Chica de la región de Texcoco, las narrativas de los habitantes más longevos se refieren al pasado lacustre de la cuenca en un sentido más experiencial. Estos pueblos hacen parte de quienes el arqueólogo Jeffrey Parsons (2006) definió, todavía a finales del siglo pasado, como "los últimos laguneros" de la cuenca, época en la que todavía algunos de sus habitantes aprovechaban el lago para subsistir. Quizá, es por ello que no es el orgullo y el optimismo lo que motiva sus narrativas sobre aquel pasado lacustre y sobre el proceso en sí mismo de la desecación, sino más bien, una sensación ambigua de estos últimos mezclados con sentidos de desgracia y abandono.

Replantear la desecación como desastre implica reconocer explícitamente que las condiciones materiales que comprenden los entornos urbanos están controladas, manipuladas y sirven a los intereses de la élite, a expensas de las poblaciones marginadas (Swyngedouw 2004). Entender al desagüe de la cuenca como desastre, exige, entonces, dar cuenta de las desigualdades que le subyacen y las que provoca; de las relaciones a menudo tensas y conflictivas entre los imaginarios de modernización y urbanización; y de los costos sociales, económicos y ecológicos reales que generan la realización de esos imaginarios en ciertos lugares (Kaika, 2006). Es también, desde esta perspectiva, que tiene cabida la articulación entre la desecación y los procesos de despojo.

\section{El desagüe como desastre del desarrollo}

El tema del agua en la cuenca de México, entendida como una crisis, ha sido ampliamente analizado y discutido en relación con la gestión (privada, pública y comunitaria), a la escasez, a sus intercambios y trasvases (local, regional), a la sobreexplotación de los mantos acuíferos y a los conflictos sociales por el agua ${ }^{4}$. Sin embargo, en menor medida, el agua ha sido abordada como factor de injusticia, inestabilidad social y política, 
en tanto desastre. Por su parte, los estudios que han trabajado el agua en relación con el desastre, han centrado su análisis en las inundaciones que se suscitan en diferentes lugares de la ZMVM, principalmente durante las temporadas de lluvias 5 .

La contribución de este artículo a estas discusiones tiene que ver con pensar el desastre del agua no sólo en su presencia abundante y repentina, sino a la contracara de este tipo de sucesos: la desecación, un proceso de pérdida de cuerpos de agua que se sucede de manera gradual. Esta perspectiva es relevante porque la inundación y la desecación son dos procesos contradictorios que, paradójicamente, se entienden de manera relacional en el caso de la ZMVM. Se drenaron los lagos para evitar las inundaciones, pero sólo tiene sentido pensar en la inundación como desastre, cuando reconocemos que esta megalópolis se ha drenado artificial, cotidiana e históricamente. Por lo que podemos hablar tanto de desastres por inundación, como también de desastres por desecación.

La historia de desagüe de la cuenca ha sido una empresa transmilenaria y, de cierta forma, gradual. Durante los últimos setenta años, a partir del modelo de desarrollo industrial que posibilitó la expansión de la mancha urbana de la Ciudad de México y atrajo más población rural a la ciudad, la desecación de los cuerpos de agua que quedaban ha sido mucho más dramática, lo que afectó las formas de vida de las poblaciones que habitaban o aún habitan a sus orillas y que así lo han hecho por varias generaciones.

En ese sentido, si como lo ha planteado Oliver-Smith (1998), una característica de los desastres es que estos "disrupt routine life, destabilize social structures and adaptations and endanger world-views and sytems of meaning" (p. 182), entonces es posible pensar que la desecación de un cuerpo de agua es, sin duda, un desastre. Pues, como ya se ha documentado en otros estudios, la pérdida de un cuerpo de agua altera la vida cotidiana de los pueblos que han estado históricamente asociados a un modo de vida ribereño o lacustre (Sugiura, 1983; 2015; Albores, 1995).

Por otro lado, es posible pensar la desecación de la cuenca como un desastre, en tanto que, más que ser resultado de un proceso unifactorial, ha sido resultado de la intersección de un conjunto de procesos sociales, ambientales, culturales, políticos, económicos, físicos y tecnológicos interrelacionados (Oliver-Smith, 1998; 2020). Asimismo, es preciso tener claro que el desastre de la desecación (y los desastres en general) es producto 
de la acumulación de riesgos y de vulnerabilidades propiciados por los modelos y políticas de desarrollo (o sea, por decisiones políticas) que refuerzan las desigualdades sociales y afectan de maneras particulares y más violentas a las poblaciones marginadas (Acosta, 2005, p. 22).

En este sentido, aunque estoy hablando de un tipo de desastre que se asemeja a la desertificación, y que responde también a condiciones hidrometeorológicas, la desecación está estrechamente vinculada a decisiones políticas a favor del desarrollo y crecimiento urbano. Por un lado, se considera que el desarrollo de las mega infraestructuras de desagüe del Valle de México, históricamente, han mejorado la resiliencia ante las inundaciones, particularmente a través de la tecnología e innovación ingenieril. Por otro lado, también los procesos vinculados con el desarrollo o impulsados por él generan una mayor vulnerabilidad y exposición a desastres por inundación o por desecación. De ahí que el caso de la desecación de cuerpos de agua en la experiencia de los pueblos originarios ribereños de la cuenca, puede pensarse como un desastre a casusa del desarrollo, tal como lo ha sugerido Oliver Smith $(2009 ; 2010)$.

En un esfuerzo por ampliar la mirada antropológica de los desastres, este antropólogo -junto a su grupo de investigación- (ver OliverSmith, 2009), han planteado que al mirar la dimensión social, política y económica de los desastres "naturales", es posible vislumbrar que, así como sucede con los huracanes o terremotos, también la construcción de un represa, de una infraestructura carretera o inclusive de un proyecto de desarrollo turístico, tienen todos ellos muchas veces efectos parecidos: reasentamientos, desplazamientos forzados y en muchos casos también la exigencia de la reparación por parte de las poblaciones locales.

Si notamos cómo en cualquier de los casos mencionados anteriormente los desplazamientos de humanos y no humanos han sido consecuencia de modelos de desarrollo que han producido desigualdades y vulnerabilidades previas al desastre, lo que podemos apuntar es que más que desastres naturales son desastres del desarrollo. En palabras de Rose (2009): "Those cases in wich goverment condemn and seize land related resources in the name of economic development yet fail to povide due processs, including meaningful compensation for losses and related injury" (p. 213).

Lo que observo de manera particular en el caso de la desecación de la cuenca de México es que, sin duda, ha sido impulsada por un largo y complejo proyecto de desarrollo urbano. Este proyecto ha privilegiado a ciertos actores del capital privado, a las elites políticas y a las poblaciones 
centrales; quienes se benefician con el crecimiento incesante de la metrópoli a través de la concentración de poder, de recursos y del diseño de una ciudad de competencia global. Sin embargo, la desecación como desastre del desarrollo no ha tenido como efectos únicamente el desplazamiento o el reasentamiento de poblaciones. En el caso que trataré aquí, la desecación de sus cuerpos de agua ha traído como consecuencia el desplazamiento de ciertas relaciones sociales productivas y reproductivas, pero no ha habido un reasentamiento de toda una población hacía otro lugar. En cambio, lo que sí acontece como resultado, y al mismo tiempo como causa de este desastre, son varios procesos de despojo que han cobrado distintas modalidades en determinados momentos históricos.

\section{Desentrañando los encuentros entre desastres y despojos}

El estrecho vínculo entre desastre y despojo ha sido abordado previamente por algunas autoras y autores que sugieren cómo las situaciones de desastre han resultado proclives para la acumulación de capital mediante procesos de acaparamiento de bienes comunes, ya sea intencionalmente o como resultados inesperados de políticas de mitigación y reparación. Para el caso de Puerto Rico, Rhiney $(2019 ; 2020)$ ha analizado cómo, luego de la temporada de huracanes del año 2017, los esfuerzos de recuperación se utilizaron como estrategias para la acumulación de nuevas formas de capital global a través del despojo de tierras, cada vez más basado en nociones de resiliencia y reubicación ante la detección de zonas de riesgo (Popke y Rhiney, 2019).

Sin embargo, si partimos de que el despojo tiene que ver con mucho más que el arrebato de la tierra (Hart, 2016), hay otros estudios que han dado cuenta de los vínculos entre desastre y despojo, aludiendo a las formas sutiles en que éste último se presenta. Camargo y Ojeda (2017) han analizado este vínculo para el caso de dos comunidades en el Caribe colombiano en el contexto de las inundaciones ocasionadas por el fenómeno La Niña en el año 2010. Los autores muestran cómo los discursos informados globalmente sobre adaptación y mitigación del cambio climático se experimentaron localmente como despojo y marginalidad, pues las medidas implementadas por el Estado terminaron exacerbando el tipo de vulnerabilidades que supuestamente debían contrarrestar. Este despojo se experimenta en la separación de sus espacios cotidianos tanto domésticos como de producción, así como en el desarraigo territorial y de los modos de pertenencia de los habitantes locales.

Pensando en el despojo producido por el desastre de las inundaciones en el Valle de México, Chahim (2020) ha sugerido por su parte 
que, si bien los desplazamientos de agua mediante las infraestructuras de drenaje no se apoderan de la tierra de las personas, sí las despojan de algo más intangible: el sentido de seguridad o tranquilidad que provoca la incertidumbre de ser víctimas frecuentes de las inundaciones; lo que sucede principalmente en las zonas periféricas y más precarizadas de la metrópoli. Por su parte, Bonilla (2020) ha señalado, también para el caso de Puerto Rico, cómo las formas de despojo constituyen y además desencadenan los desastres en una trama racial y colonial. La autora se refiere a una «violencia lenta» aplicada por parte del gobierno colonial, que prepara el escenario para un acelerado despojo evidenciado en estado de emergencia. Cercana a la reflexión de Chahim (2019), Bonilla (2020) propone la idea de la espera del desastre o la espera de la reparación como una forma de pérdida del sentido de la seguridad, otra modalidad del despojo sutil, pero sumamente violento.

En el contexto de estos planteamientos, recolocar el desecamiento de la cuenca de México desde la mirilla de las narrativas subalternas, contribuye a los análisis sobre las diversas y cambiantes formas del despojo que desde la etnografía se pueden aprehender (Li, 2009) y que son resultado de o se encadenan a partir del desastre. Despojos que no siempre son interpretados en términos de propiedad o de arrebato de bienes ni conducen necesaria o directamente a la acumulación de capital. Lo que muestro, a partir de una reconstrucción etnográfica de la historia de los pueblos a la orilla oriental del Lago de Texcoco, son las formas más sutiles de despojo provocadas por un tipo de desastre que no fue repentino sino progresivo. En ese sentido, entiendo el despojo que la desaparición de un cuerpo de agua produce, como sugieren Bluter y Athanasiou (2017): "Una condición dolorosa impuesta por la violencia normativa y normalizadora que determina los términos de subjetividad, supervivencia y rasgo de lo vivible" (p. 17).

\section{Los pueblos a la orilla del lago de Texcoco y la Sirena}

La región llanamente conocida como lagos y volcanes de Anáhuac, que ocupa una extensión importante del Altiplano Central de México, se ha distinguido por una larga historia en donde los grupos humanos interactuaban estrechamente con su entorno lacustre. Se han registrado numerosos vestigios arqueológicos que constituyen testimonios palpables de aquellas poblaciones en los valles centrales de México cuya vida se desarrollaba alrededor de lagos y lagunas, inclusive ya desde el año 1500 a.C (García, 2002; Parsons, 2006; Parsons y Whalen, 1982; Serra Puche, 1998). De esta manera, el vínculo entre los grupos humanos y el medio lacustre no sólo tiene una historia remota, sino también ha dejado huellas 
profundas en la vida cotidiana de varias poblaciones del Anáhuac. Los pueblos originarios de la ribera oriental del lago de Texcoco no son la excepción.

Santa Isabel Ixtapan, San Cristóbal Nexquipayac, San Francisco Acuexcomac, San Salvador Atenco, San Miguel Tocuila y Santa Cruz de Abajo, son nombres de los pueblos originarios (con establecimientos prehispánicos) que conforman lo que entre los habitantes de los municipios de Texcoco y Atenco se conoce como "la Costa Chica". Formando una especie de corredor, las entradas principales de estos pueblos, adornadas con arcos de flores durante sus fiestas patronales, se encuentran una tras otra a lo largo del tramo Lechería-Texcoco de la carretera federal 142 (Figura 3).
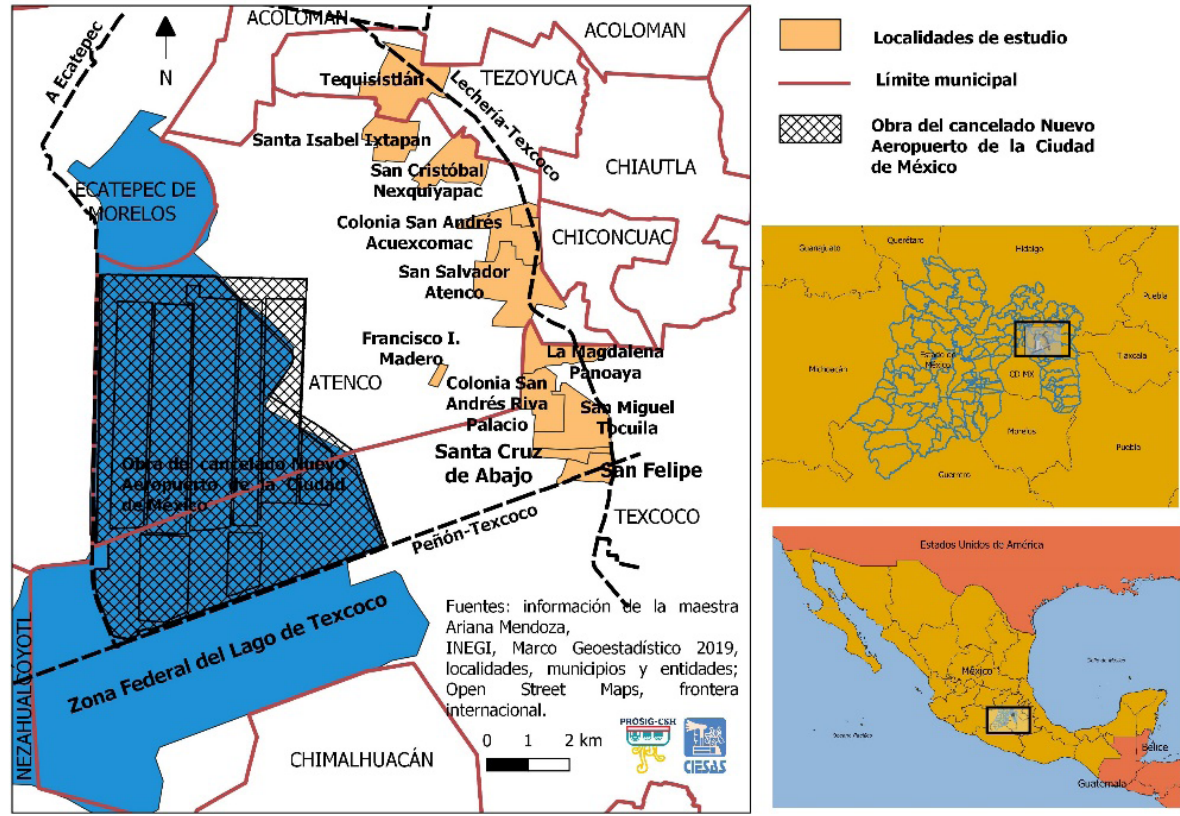

Figura 3. El avance de la ciudad sobre las zonas de cultivo de los pueblos de la Costa Chica de Texcoco y el lecho del lago.

Fuente: información de campo de Ariana Mendoza, INEGI, Marco geoestadístico 2019; localidades, municipios y entidades;

Open Street Maps, frontera internacional.

En lo que podríamos llamar el traspatio de estos pueblos se encuentran sus tierras ejidales, todas ellas colindantes a la Zona Federal Lago de Texcoco. Las tierras de este antiguo cuerpo de agua todavía, en las primeras décadas del siglo pasado, cubría gran parte de lo que ahora son parcelas de cultivo, asentamientos urbanos informales y las ruinas de 
un aeropuerto inconcluso. De ahí que estos pueblos sean identificados entre los habitantes de la región texcocana como costeros o ribereños, en alusión a su antigua vecindad con el lago. El mismo nombre del municipio de Atenco que procede del náhuatl, la lengua hablada antiguamente en estos pueblos, hace referencia a esta histórica vecindad. Conformada por los vocablos atl (agua) y tentli ("orilla" o "filo de cuchillo"), la palabra Atenco traducida al castellano significa "lugar a la orilla o al margen del agua".

Sin embargo, el mítico lago, tal como las reconstrucciones etnohistóricas y arqueológicas lo han descrito (Apenes, 1943; Espinosa, 1996; Rojas-Rabiela, 2009), ya no existe. El traspatio de los pueblos pasó de ser un ecosistema lacustre y principal medio de reproducción de la vida de los pueblos, a ser un paisaje de intervenciones hidráulicas que ayudan a desaguar la metrópoli de la Ciudad de México. Más recientemente este ecosistema se convirtió en el polígono de construcción de una gigantesca infraestructura aeroportuaria iniciada en el año 2015 y cancelada tres años después ante la presión política -local y nacional- en contra de su edificación.

Todavía a inicios de este siglo, la zona lacustre se resistía a morir. Algunos descendientes de los antiguos pescadores luchaban por no abandonar el modo de vida legado por sus antepasados, más motivados por la nostalgia o alguna situación de emergencia económica que por lo que realmente representaban estas actividades en sus economías familiares. Aunque, ciertamente, lo que se presenciaba en ese entonces estaba lejos del esplendor que narran actualmente algunos ancianos y ancianas al referirse a sus infancias vividas durante la última mitad del siglo pasado. Un periodo en el que la vida estaba estructurada, en gran medida, alrededor de las bondades -y también amenazas- del medio lacustre.

Todavía en la década de 1970, varios pobladores fabricaban y usaban redes cosidas al halo, fisgas de metal o madera, anzuelos, canoas y otros artefactos para obtener algunas especies animales y vegetales de zonas pantanosas o pequeños cuerpos de agua. Los acociles y atepocates, especies animales endémicas de la cuenca, y otros pequeños peces, así como una serie de plantas acuáticas y semi acuáticas eran recolectados. Cazaban ranas en época de lluvias, y en el invierno, cuando llegaban las aves migratorias, se atrapaban algunos patos con redes o se organizaban cazas colectivas conocidas como "armadas". Los huevos de patos y otras especies de insectos y aves eran también importantes como alimento. Hoy día, algunos ancianos ex trabajadores del lago, recuerdan vagamente la detallada y complicada técnica para cosechar ahuautle, los huevecillos de 
un insecto que abundaba en las ciénagas del lago y que hoy día se recuerda con añoranza.

Reiteradamente, las y los ancianos narran este pasado lacustre en clave gastronómica, al remitirse a los sabores, las técnicas y la variedad de las especies usadas en los platillos de origen lacustre que las familias consumían a diario, y a partir de los cuales estas personas explican su buena condición de salud actual y su longevidad. En estos días, con entusiasmo, solo se extrae del lago, en época de cuaresma, los romeritos, una especie vegetal que crece muy bien en los suelos salitrosos de su lecho. También unas cuantas personas extraen tequesquite, la sal de tierra que es posible obtener a partir de una antigua técnica local de tratamiento de los mismos suelos expuestos. Una actividad productiva que anteriormente tenía mucho dinamismo en la época de sequías y que ahora solo funciona como actividad complementaria para los gastos de una decena de familias en San Cristóbal Nexquipayac y Santa Isabel Ixtapan.

Los testimonios apuntan también hacía la importancia social de los cuerpos de agua, pues dieron a los lugareños un fuerte sentido de pertenencia y el orgullo de ser vecinos del lago fundante de la nación. Así lo evidencian las imágenes del lago que cuelgan de las oficinas de las autoridades locales, los murales que hacen referencia a la fundación de la ciudad sobre los cuerpos de agua y los mismos apelativos de cada pueblo, que refieren en lengua náhuatl a diferentes aspectos del antiguo modo de vida lacustre (por ejemplo, Ixtapan: lugar de sal).

Hoy día, muchos de los antiguos artefactos usados en el trabajo del agua se encuentran en los graneros o bodegas de las casas más viejas de estos pobladores, como parte de la constelación de escombros (Gordillo, 2014) que han quedado de aquel antiguo lago y del modo de vida lacustre. Actualmente el paisaje y sus habitantes se encuentran inmersos en un fuerte proceso de urbanización. Sus tierras de cultivo se debaten entre la continuidad de la producción agrícola y la emergencia de colonias irregulares que han sido fundadas por la población marginada de la metrópoli, quienes encuentran en estas tierras la oportunidad de hacerse de un lugar donde vivir aún en condiciones precarias. Los habitantes ribereños, quienes eran antiguamente trabajadores del agua y posteriormente fueron campesinos, pasaron a ser hoy día sujetos con una economía informal, precarizada y diversificada en la que la agricultura tiene un papel secundario, y el trabajo de laguneros ni siquiera figura en los censos oficiales. 
Esta historia de transformaciones tiene como correlato el desastre de la desecación de la cuenca, por lo que, con este proceso, se perdió no solo el cuerpo de agua texcocano, sino sentidos de vida y una serie de conocimientos locales adquiridos a través de las propias experiencias de los habitantes ribereños y de las prácticas heredadas. Conocimientos y habilidades en cuanto a qué, cuándo, dónde y cómo apropiarse de variados recursos que las ciénagas les ofrecían. En este sentido, la narrativa de la Sirena da cuenta de cómo vivir dentro de un paisaje perturbado es una experiencia socionatural que involucra narraciones y representaciones que dan significado a este paisaje sumamente transformado (Tsing, 2015; Berglund et al., 2019), así como a los procesos que lo producen y sus efectos en la vida de las personas.

Junto a la pérdida del cuerpo de agua como medio de producción de los antiguos laguneros, el mito de la Sirena evoca también un despojo ontológico. Parafraseando a Diana Ojeda (2016, p. 22), el mito evoca la pérdida de "eso que no se puede volver a ser": pueblos a la orilla del lago. Desde esta perspectiva, propongo considerar, junto a Butler y Athanasiou (2017, p. 17), que las personas podemos ser desposeídas también en la medida en que sentimos pena por algo que hemos perdido o sufrimos una pasión, digamos, "en esos momentos en que somos incapaces de encontrarnos a nosotros mismos" o algo nos pone "fuera de lugar".

Sin embargo, aislada, la alegoría de la Sirena elude la responsabilidad histórica de quienes han puesto "fuera de su lugar" a estos pueblos, de los actores que motivaron su desecación. Sólo recurriendo al mito no podríamos discernir qué secó la laguna, qué transformó ese paisaje, quiénes o cómo. No obstante, conociendo los relatos de vidas personales y familiares y situándolos en la historia más amplia del crecimiento de la ciudad, aparecen las respuestas: "fue Conagua" (Comisión Nacional del Agua), "fue el gobierno", "fue el dichoso aeropuerto", "fue el crecimiento de la ciudad". Todo apunta hacía proyectos de desarrollo impulsados por el capital privado y el Estado. De esta manera, aunque el proceso de la desecación se ha registrado en la narrativa local como un acontecimiento (la huida de la Sirena), los pobladores llevan implícito en los testimonios de sus trayectorias de vida que éste ha sido un desastre progresivo con secuelas en el tiempo.

Son estas secuelas progresivas y acumulativas que se concretan de la vida cotidiana y encarnan en trayectorias de vida específicas, las que me interesa destacar a continuación a partir de contar, desde un lugar particular, la historia de la desecación de la cuenca. Un proceso de largo aliento que ha suscitado y se ha articulado a varios procesos y modalidades de 
despojo que podemos mirar a partir de tres momentos: la etapa posrevolucionaria que dio impulso a la modernización agrícola; la época del desarrollo urbano e industrial; y el más reciente, que responde al empuje de la ciudad neoliberal y global.

\section{Se llevaron la laguna, pero repartieron ejido}

A inicios del siglo XX el proyecto civilizatorio de la desecación de la cuenca, iniciado en el régimen colonial y continuado en el México independiente, tuvo continuidad y efectos particulares en los pueblos a la orilla oriental del lago de Texcoco. Como sucede hasta hoy, en las primeras décadas de este siglo, el vaso del lago de Texcoco cumplía el papel estratégico de ser receptor de los drenajes de la ciudad (donde se mezclaban las aguas de lluvia y las aguas negras) para desde ahí ser expulsados de la cuenca por medio de otros canales que allí se conectaban.

Es así que, cruzando los terrenos ejidales de los pueblos, hacía el corazón del lago, durante el periodo anual de lluvias, se conformaban medianos cuerpos de agua. Mientras que, durante el periodo de sequía, lo que quedaba era un gran desierto de suelo inestable, agrietado, salino y contaminado por los desagües de la Ciudad de México. De estas circunstancias se originaban inmensas tormentas de polvo que llegaban hasta el centro de la ciudad provocando daños a la salud. Además de un fétido olor en el ambiente (Vitz, 2018 y Cházaro, 2014).

El señor Alfonso Vargas, del pueblo de Santa Isabel Ixtapan, recuerda que algunos habitantes de los pueblos que trabajaron en "hacer las zanjas de la laguna para desaguarla" durante la década de 1930, perdían el rumbo en su camino desde el lecho del lago hacía los pueblos. Las marejadas de polvo que se levantaban les impedían ver más allá de una cortina blanca de polvo, haciéndolos dar vueltas sobre el mismo lugar. Sin embargo, aunque los pueblos costeros también se veían afectados por la desecación, fue desde la ciudad de donde se hicieron escuchar las preocupaciones por los daños a la salud que los polvos salitrosos y contaminados causaban (Vitz, 2018). Esta situación instó a una serie de iniciativas del gobierno, las cuales buscaban resolver el problema de salubridad que representaba el lago (Vitz, 2018 y Cházaro, 2014).

Aunque existieron propuestas que llamaban a su recuperación lacustre, la tendencia, influenciada por el espíritu posrevolucionario y la presión del crecimiento de la ciudad, fue optar por el drenaje total y definitivo del lago para, posteriormente, realizar un proceso de lavado de sus sales y fertilizarlos, con miras a convertirlos en tierras para uso agrícola 
(Vitz, 2018 y Coloballes, 2019). Esto permitiría no sólo dar respuesta al problema sanitario sino también al apremio de la reforma agraria que, durante el periodo posrevolucionario, buscó ampliar la frontera agrícola e institucionalizar las demandas agrarias de la insurrección campesina iniciada a principios del siglo XX.

En este contexto, y a diferencia de lo que sucedió en el resto del país (Arias, 2019), los pueblos originarios a la orilla oriental del lago fueron de los primeros en ser dotados de tierras ejidales a lo largo de la década de 1920 (Rosas Vargas, 2013). A estos pueblos se les restituyeron tierras que habían sido propiedad de las haciendas cercanas, pero en gran medida se les repartieron las tierras que el lago fue dejando libres conforme su desagüe avanzaba. Inclusive, aún después de la dotación, y como hasta ahora sigue sucediendo, los padres y abuelos de los últimos laguneros que aún viven, apelaron a su posición como pobladores originarios de la orilla del lago para exigir su derecho de adhesión a esas tierras en virtud de la retirada de las aguas (Vitz, 2012 y Rosas Vargas, 2013).

Desde entonces, como me señaló un ejidatario de San Salvador Atenco: "nuestros padres nos enseñaron a defender ese territorio, con laguna o sin laguna. Ahora hasta con aeropuerto, es nuestro". Bajo esa lógica, los ejidos de San Isabel Ixtapan y San Miguel Tocuila solicitaron la ampliación de su ejido hacía las tierras que fueron quedando "libres" con la desecación, en 1934 y 1935 respectivamente. Asimismo, en 1932, a partir de otra porción de tierras ganadas al lago, se creó el ejido de Santa Cruz de Abajo.

Para la década de 1940, sin embargo, todavía existían pequeños cuerpos de agua llamadas localmente como lagunas o charcos. Ahí la gente aún aprovechaba las especies lacustres para su autoabastecimiento y para el intercambio comercial. La gente de la costa intercambiaba productos con los pueblos de la sierra Texcocana o viajaba al centro de la Ciudad de México a ofrecer productos lacustres. En ese contexto, la dotación de tierras ejidales permitió, en ciertos casos, complementar las economías familiares hasta entonces basadas fundamentalmente en el aprovechamiento del lago con la producción agrícola a pequeña escala.

Sin embargo, la trasformación no fue fácil. Los ejidatarios tuvieron que trabajar en el acondicionamiento de estos suelos salinos antes de poder sembrar y hacerlos producir, mediante un proceso largo conocido localmente como "lavados de tierras". En varios casos, ni con estos "lavados", las tierras fueron fértiles para la producción del maíz para autoconsumo -el principal producto alimentario de la región-, sino únicamente para 
ciertas especies destinadas exclusivamente al forraje para los animales domésticos, como la alfalfa y la remolacha. Otro problema que también complejizó el proyecto de la modernización y ampliación de la frontera agrícola a costa del lago, fue la disponibilidad de agua e infraestructura para riego. No todos los ejidos pudieron beneficiarse de ésta, por lo que tuvieron que limitarse a la producción agrícola de temporal.

Lo que quiero resaltar en esta etapa del desastre de la desecación es cómo, si bien se despoja gradualmente del principal medio de vida de los pueblos ribereños: el lago, irónicamente este despojo fue productivo para los despojados. No sin producir nuevas desigualdades y potenciar algunas que le precedían, la desecación del lago posibilitó el reconocimiento a los pueblos costeros, de la propiedad colectiva de las tierras que éste fue dejando. Así, este despojo gradual del cuerpo de agua produjo, contrario a lo que podríamos suponer siguiendo la narrativa teleológica "despojo, entonces acumulación de capital" (Ojeda, 2016, p. 25), no el cercamiento o privatización de una propiedad colectiva, sino justamente el reconocimiento de un bien colectivo: el ejido. Sin embargo, los efectos de esta contradicción fueron desiguales. Las mujeres no se vieron beneficiadas en este proceso. Fueron los hombres, categorizados como jefes de familia, a quienes la Ley Agraria reconoció -y sigue reconociendo hasta hoy díacomo titulares de las tierras, por lo que es necesario apuntar también las formas diferenciales en las que el desastre y el despojo afectan al interior mismo de las poblaciones.

Por último, lo que podemos ver también es que este periodo de la desecación trajo consigo una desposesión del sentido y de las prácticas de lo común, entendiendo a éste, no únicamente como propiedad o cosa, sino como relación social; es decir, "el hacer social orientado al valor de uso que garantiza y cuida aquello que se comparte para producir la vida" (Navarro, 2015, p. 23). Desde esta perspectiva, con la pérdida del lago se da también el proceso de producción de lo que Butler y Athanasiou (2017) llaman un "individualismo posesivo" y profundamente patriarcal (Federeci, 2010), articulado a la figura del ejido. Proceso que depende de "la negación de modos de existencia más primariamente sociales, dependientes y relacionales" (Butler y Athanasiou, 2017, p. 24), en este caso, el modo de vida lacustre.

\section{De laguneros a albañiles, obreros y trabajadoras del hogar}

Al indagar entre los pobladores ribereños sobre cuando sucedió la huida de la Sirena, es imposible obtener una fecha o año específico, pero todos los testimonios coinciden en una época: mitad de la década de 1950, 
finales de la década de 1960. Esta fecha no es fortuita. Conociendo las historias de vida de varios de los pobladores de mayor edad, es posible darse cuenta de que todos se sitúan en este periodo de tiempo para explicar grandes cambios en sus vidas o en las vidas de los pueblos. Aquella es una época parteaguas, en el sentido literal y metafórico del término. En ese entonces, comenzó a ser más sentido y percibido por aquellos pobladores que el lago estaba retrocediendo. Los pequeños cuerpos de agua que se formaban como resultado de las venidas de los ríos que anteriormente alimentaban al lago, cada vez estaban más contaminados por el incremento de la descarga de drenajes y aguas industriales de la zona urbana de Texcoco, que creció de manera rápida en aquellas décadas.

Del largo proceso de agotamiento del lago, la etapa situada entre 1950 y 1960 tuvo entonces consecuencias trascendentes para los pueblos. Hubo una transformación de las relaciones sociales basadas en el aprovechamiento de la laguna, para dar paso al proceso de expulsión de los antiguos "laguneros" hacía los centros urbanos e industriales más cercanos. De manera semejante a lo que Taussig (1993) planteó para el caso de las imaginerías diabólicas en Colombia, la huida de la Sirena puede ser entendida como una reacción y explicación mítica sobre la transformación de un modo de vida basado principalmente en valores de uso, y que dio paso a un modo de vida cada vez más fundamentado en los valores de cambio.

En ese periodo de tiempo, gran parte de los trabajadores lacustres y agrícolas, sobre todo los más jóvenes, empezaron a incorporarse a otras actividades. Las mujeres se emplearon como trabajadoras domésticas en las nuevas zonas residenciales emergentes circundantes. Los hombres se emplearon en la albañilería y como obreros en el corredor industrial que se estaba configurando en el norte de la ciudad, en los municipios vecinos como Ecatepec y Naucalpan.

Una de las empresas que marcó el auge del desarrollo industrial de Ecatepec fue Sosa Texcoco S.A. Una paraestatal que fue parte del proyecto de desarrollo industrial que buscaba aprovechar el lecho del lago ya para entonces casi completamente seco. Esta empresa aprovechó los suelos salinos expuestos del lago para la producción de soda caustica. En esta industria', fueron empleados algunos de los pobladores de estos pueblos ribereños, aprovechando sus conocimientos sobre la configuración y manejo de los suelos del lago, además de su cercanía.

Industrias como Alcan Aluminios y Almex, ambas fabricantes de aluminios, ahí mismo en Ecatepec, así como el sector servicios en las 
instituciones educativas ${ }^{6}$ que se instalaron en la región de la mano de proyectos de vivienda para su comunidad de profesores, fueron otros nichos de trabajo en donde se emplearon estos campesinos y ex trabajadores del agua. En este contexto fue que Tocuila ganó la fama de ser "un pueblo de buenos albañiles", como hoy día se escucha decir orgullosamente en aquel pueblo. Muchos campesinos comenzaron a especializarse en este oficio y trabajar en distintas obras en la Ciudad de México y la entonces creciente urbanización de Texcoco.

La incorporación de los laguneros a la albañilería se correspondía con, y a la vez fue resultado de, la política económica del país que entre los años de 1945 y 1970 estuvo orientada a promover la expansión y desarrollo de la industrialización, ocasionando el crecimiento de las áreas urbanas e industriales en la ciudad y la expulsión de los pequeños productores del campo, que se vieron desplazados por el modelo de industrialización agraria e industrial.

Desde esta perspectiva, se ha desarrollado un argumento generalizado en relación a que la política de sustitución de importaciones creó las condiciones para producir sus propios trabajadores dispuestos a vender su fuerza de trabajo, expulsándolos del campo para incorporarse a las nuevas dinámicas de acumulación de capital centradas en la industrialización. Sin embargo, para el caso que aquí trato, este argumento necesita ser ampliado para considerar cómo la política de la industrialización produjo no solo condiciones económicas, sino ambientales, que hicieron posible la liberación de fuerza de trabajo. Para los pueblos ribereños de Texcoco, la expansión del mismo proceso de urbanización a costa del desecamiento del lago, contribuyó a deteriorar las condiciones socioambientales, las cuales posibilitaban el trabajo de los antiguos laguneros en sus cuerpos de agua y sus tierras de cultivo.

Sin embargo, la incorporación de los antiguos laguneros al proceso de industrialización no se dio de manera "natural". Algunas personas combinaron su trabajo, como obreros, albañiles y trabajadoras domésticas, con el trabajo de la tierra y la ganadería a pequeña escala. Ya fuera porque sus ingresos no resultaban suficientes para garantizar la subsistencia de las familias o porque para muchos simplemente era importante continuar con el trabajo del campo en términos de un compromiso social, el hecho fue que éste no fue un proceso completo de salarización. Hasta nuestros días, los pobladores de esta ribera, ya sumamente urbanizada, se 
caracterizan por una economía precarizada que depende de la economía informal y ve en la producción agrícola una actividad complementaria.

Es así que, en este periodo del desastre de la desecación, podemos hablar de un despojo más apegado a lo que en términos marxistas correspondería a la separación de los trabajadores de sus medios de producción, con lo cual inicia el proceso de proletarización. Sin embargo, este caso tiene ciertos matices: esta escisión entre los productores y sus medios de producción, tiene particularidades que sugieren pensar en las formas insidiosas en que sucede el despojo. Si bien en esta época tampoco fueron tierras ni un bien colectivo del cual los pueblos tuvieran posesión, las que se cercaron o arrebataron -como lo sugiere Ojeda (2016, p. 21)-, es posible ver al despojo ocurrido a partir de la contaminación y disminución de los cuerpos de agua como "un proceso violento pero gradual de reconfiguración socioespacial y, en particular, socioambiental, que limita la capacidad que tienen las comunidades de decidir sobre sus medios de sustento y sus formas de vida".

Los pueblos ribereños se encontraban sin apoyo para sistemas de riego, con un ciclo de lluvias cada vez más incierto y sin cuerpos de agua para aprovechar las especies lacustres. Así que, aún con el logro del reconocimiento de la propiedad colectiva de las tierras ganadas al lago, lo que aconteció finalmente fue un despojo sobre el control de su forma de vida. Se quebraron y agotaron ciertas subsistencias en términos económicos y materiales, pero también fueron anuladas, en términos ideológicos, por un proceso civilizatorio que desechaba las prácticas campesinas y lacustres opuestas a la modernidad urbana e industrial. Al mismo tiempo, el desastre de la desecación se engarzó con el proceso, ya iniciado, del despojo de las formas de reproducción comunitaria (Navarro, 2015 y Federeci, 2010), pues la entrada de la lógica de capital a través del proceso de salarización fue reacomodando las relaciones sociales al interior de los pueblos, incorporando nuevos actores sociales y mecanismos de poder a la trama del lago y sus pueblos.

\section{De lago a aeropuerto}

Hacía la década de 1970 se comenzó a ejecutar el Proyecto Lago de Texcoco, que buscaba de cierta manera la recuperación del ecosistema lacustre. Otro proyecto más que se sumaba a los intentos de resolver el incesante problema del lago. Las acciones vinculadas a dicho proyecto lograron la forestación de parte del lecho salino y se renovó parte del antiguo sistema de cuerpos de agua con la creación de una laguna reguladora conocida como Nabor Carrillo y otras tres, que cubrieron en total 
más de 2.000 hectáreas del lecho original. El proyecto se institucionalizó de tal manera que se decretó en 1971 la Zona Federal Lago de Texcoco (Soto Coloballes, 2019b, Aréchiga, 2004, Legorreta, 2006).

Con la creación de la Comisión Nacional del Agua (CONAGUA) en 1989, la instancia federal que centraliza los asuntos vinculados al agua en México, el traspatio de los pueblos ribereños pasó de ser una mancha de tierras agrícolas sin una frontera bien reconocida por los ejidatarios, a ser un nuevo arreglo territorial que implicaba reconocer que aquellas tierras ya eran propiedad del Estado. Este fue un antecedente fundamental para lo que después se suscitó en este territorio. Con el acaparamiento de estas tierras en manos del Estado, se impulsó el proyecto de construcción de una nueva terminal aérea para la Ciudad de México, lo que trajo una nueva ola de despojos, pero también la continuación del desastre de la desecación bajo otras modalidades.

El 22 de octubre del 2001, el gobierno federal publicó 19 decretos expropiatorios con los que 5,390.7600 hectáreas de propiedad ejidal pasarían a manos del gobierno federal. Sin reconocer el derecho a la consulta de los pueblos, estos terrenos serían destinados para la construcción del nuevo aeropuerto, bajo el argumento de los fines de utilidad pública (Camacho, 2008). Fueron trece ejidos los que se veían directamente afectados? ${ }^{7}$. La expropiación implicaba a 171 viviendas que tendrían que ser reubicadas en el municipio vecino de Ecatepec, para lo que se implementaría un esquema de apoyos, consistentes en la entrega de materiales de construcción y pies de casa para la edificación de las mismas (Camacho, 2008).

Sin embargo, la "reubicación" era, y sigue siendo, interpretada por los pobladores como "desaparición", la "utilidad pública" como "injusticia". Casi veinte años después, los pobladores ribereños recuerdan con indignación que entonces el gobierno federal pretendía pagarles $\$ 7.20$ pesos por parcelas de temporal y $\$ 25$ pesos por parcelas de riego. Sin embargo, en aquellos años, "el dinero era lo de menos". Dice don Margarito: "lo que creo que nos dolió en verdad a todos era saber que el pueblo tendría que desaparecer casi por completo...el panteón, el parque de ahuahuetes, casas...y eso fue lo que nos unió para luchar". 
Como sugieren Butler y Athanasiou (2017), en tanto que la desposesión es sentida, conmueve, también es constituida como una "forma de receptividad que da lugar a la acción y a la resistencia" (p. 13). De tal manera, desde que fueron emitidos los decretos, se inició un fuerte proceso organizativo que luego de nueve meses de movilizaciones y varios procesos judiciales emprendidos contra las expropiaciones, lograron su cancelación diez meses después (Camacho, 2008). Sin embargo, la historia no terminaría aquí, otros mecanismos se pusieron en marcha por parte del Estado para reactivar el proyecto aeroportuario años después.

Para evitar el recurso de la expropiación, que ya era políticamente inviable, el Estado y las empresas privadas interesadas en el negocio aeroportuario, quienes fungieron como socias y asesoras del primero, orquestaron un proceso sigiloso de compra-venta de tierras ejidales entre los años 2008 y 2014 (Vázquez 2018, 2020a y 2020b). Estas adquisiciones se hicieron bajo amparo de la CONAGUA, usando el imaginario del regreso del lago como argumento para legitimar el acaparamiento de casi 3 mil hectáreas de tierras en manos del Estado, bajo el supuesto de que serían parte de un proyecto ecológico que buscaba recuperar el ecosistema lacustre (Vázquez, 2020b). Las tierras adquiridas en esa época, sumadas a las hectáreas que ya habían sido decretadas como federales en 1971, dieron pie al comienzo de la construcción de la terminal aérea en el año 2015.

Dicho aeropuerto fue posicionado a todos los niveles como una promesa de desarrollo. Según sus promotores, de este proyecto dependía el futuro próspero de toda la nación. Así fue como recurrieron al mito fundacional de la ciudad de Tenochtitlan para posicionar discursivamente la edificación de esta infraestructura, la que, en palabras del presidente de la República en ese entonces, sería "el símbolo del México moderno" y de la ciudad global hacía la que se insiste en perfilar a la Ciudad de México en las últimas décadas, bajo políticas neoliberales y un modelo inmobiliario cada vez más clasista y privatizador.

Además, este megaproyecto marcaba una decidida continuidad con la historia del desastre de la desecación del lago. En contraste con el supuesto objetivo de recuperar el ecosistema lacustre de la zona, por el que se justificó la adquisición de estas tierras por parte de la CONAGUA, las obras de construcción del aeropuerto implicaban liquidar cualquier rastro de éste. Y es que aun sin cuerpo de agua como tal, el lecho del lago no puede ser clasificado como simplemente tierra seca.

Según los especialistas en suelos Ortiz y Gutiérrez (2015, p. 15), los sedimentos que conforman los terrenos del antiguo vaso del lago 
continúan estando muy húmedos porque están mayormente configurados por sílice amorfa, un material que tiene la capacidad de retener agua hasta 100 veces su peso. Con estos argumentos, estos autores refutan la viabilidad técnica de construir un aeropuerto en esos suelos que caracterizan como "gelatinosos". En cambio, para los ingenieros (nacionales y extranjeros) encargados del proyecto aeroportuario, construir sobre esos suelos representaba una oportunidad para avanzar y enaltecer a la misma ingeniería civil.

De tal manera, los suelos pantanosos fueron retirados con bulldozers, transportados en camiones de carga pesada y, finalmente, fueron depositados en socavones de antiguas minas en la misma región texcocana. En otro momento estos lodos se sustituyeron por toneladas de material pétreo conocido como tezontle y también por basalto: ambos materiales extraídos de alrededor de 180 minas localizadas en varios de los cerros de municipios vecinos. Todo esto intensificó los procesos de contaminación del acuífero y del ambiente debido a los altos contenidos tóxicos de los materiales que se removieron por toda la región y los impactos socioambientales que la actividad minera tuvo en las zonas altas.

En este periodo, el desastre de la desecación llegó a modalidades que rayaban en la ficción, según el sentido común de los pobladores ribereños. De forma irónica, un hombre de aproximadamente 40 años, originario del pueblo de Santa Isabel Ixtapan, me señaló alguna vez: "es imposible construir algo sobre esos lodos [...] el lago ya no es lago, pero sí es muy fangoso [...] a menos que haya manera de exprimirlo, así como a una jerga". De forma casi inverosímil, frente a esta lógica, la intensión de depositar las grandes cantidades de materiales pétreos antes mencionadas, era justamente exprimir el lago. La presión que ejercía el depósito de estos materiales provocaba la sobrecarga de los suelos, lo que posibilitó la extracción del resto de agua con ayuda de un sistema de drenaje.

A pesar de los intentos de secar por completo el cuerpo de agua, el proyecto aeroportuario esta vez tampoco prosperaría. La presión ejercida por la suma de reclamos sobre los impactos socioambientales que ya estaban provocando sus obras, así como los que traería a futuro, lograron cancelar el megaproyecto a finales del año 2018. Junto a una coyuntura del cambio de gobierno a nivel federal y el reacomodo de fuerzas políticas a distintos niveles, la presión que condujo a la cancelación de la obra se logró también por la articulación que los opositores al proyecto aeroportuario hicieron de sus reclamos con el contexto de la crisis hídrica y el colapso ambiental de toda la cuenca. 
En este sentido, algunos expertos señalaron que el aeropuerto terminaría de colapsar a la metrópoli en términos hídricos, debido a la cantidad de agua que requeriría para la operación de la terminal aérea y la de la Aerotrópolis, su proyecto complementario. También porque drenar la humedad de los suelos intensificaría el proceso de hundimiento de la ciudad y, con ello, el incremento de las inundaciones y los movimientos sísmicos (Córdova et al., 2015). En este contexto, durante los debates sobre la continuidad de la construcción del aeropuerto, se abrió un importante espacio de discusión sobre los problemas históricos de la desecación de la cuenca. Sin embrago, la discusión la dieron principalmente los "expertos" a los que recurrieron ya sea los funcionarios públicos o el mismo movimiento opositor. Una vez más la gran mayoría de los pobladores ribereños quedaron relegados de las decisiones trascendentales sobre su territorio e, inclusive, muchos de estos pobladores estuvieron a favor de la construcción del nuevo aeropuerto.

Si bien el movimiento de resistencia que emergió durante el intento de expropiación en el año 2001 fue amplio y principalmente conformado por los pobladores locales, para la segunda ola de movilizaciones una serie de factores forjaron una realidad sumamente distinta. Entre los principales factores explicativos de este cambio se encuentra la cooptación que hubo de algunos pobladores que fungieron como operadores locales del Estado y de las empresas privadas, quienes a su vez cooptaron las asambleas ejidales y dividieron a las comunidades. Además, es importante destacar la represión policial orquestada por el gobierno estatal en el año 2006, dirigida explícitamente a los integrantes del movimiento de resistencia al proyecto aeroportuario. Lo que dejó a gran parte de la población desmoralizada y temerosa.

Por otro lado, dado que, en esta ocasión, la construcción de la terminal aérea no implicaba el desplazamiento de la población y quienes vendieron recibieron por su tierra casi treinta veces más de lo que se ofrecía con la expropiación en el año 2001, para muchos de los pobladores ribereños, el nuevo intento de construir el aeropuerto en 2014 representó, en cierto sentido, una victoria. Además, luego de las grandes trasformaciones de su paisaje y de su modo de vida lacustre, este proyecto de desarrollo reconfiguró las expectativas sobre un futuro más próspero en gran parte de la población ribereña, aun cuando eran conscientes también de sus impactos negativos. Estos sentidos contradictorios fueron sintetizados así por un anciano de 81 años del pueblo de Nexquipayac: "lo más feo ya lo vivimos, cuando se nos secó el lago, ahora qué más da, ya nadie saca provecho de esas tierras, con el aeropuerto [en cambio] quizá nuestros nietos puedan trabajar de algo mejor". 
Este periodo del desastre de la desecación ilustra muy bien cómo el correlato del despojo es la resistencia. Los sujetos despojados no solo miran la pérdida sin reacción alguna, pero la reacción no siempre resulta en antagonismo. La misma experiencia de vivir un desastre gradual, pero violento, ha llevado a los sujetos a encontrar maneras de resistir encontrando espacios de negociación u oportunidad en los mismos proyectos del desarrollo que los han conducido hasta ahí.

Por otro lado, si bien en esta época neoliberal son más claros -y más explícitamente violentos- los intentos de un despojo de tierras, primero por la vía de la expropiación y después por el acaparamiento de éstas, no queda claro si es posible hablar de acumulación por despojo (Harvey, 2004). Aunque hay duda de que el intento de terminar de desecar el lago para construir un aeropuerto en su lugar puede entenderse como una de las soluciones espacio-temporales en las que el capital sobre acumulado busca donde desplegarse, la realidad es que, hasta hoy día, en ese espacio del lago sigue sin concretarse un proyecto como tal.

Una perspectiva que nos ayudaría a pensar de qué manera el despojo tiene sentido sin la inmediata consecuencia de acumulación de capital, es el planteamiento de la socióloga Mina Navarro (2015). Para ella, el despojo no refiere solo a la depredación de bienes naturales o el cercamiento de bienes comunes, sino que también tiene que ver con el despojo de las capacidades políticas de la trama comunitaria poseedora y usufructuaria de tales bienes arrebatados. De tal forma, es posible sugerir que el poder de la desposesión no siempre opera a partir de la acumulación de capital, sino que también trabaja produciendo ciertos tipos de sujetos.

En el caso que nos atañe, si bien hay un actor antagónico claramente ubicable que ha resistido sobre todo a los últimos procesos de despojo, estos últimos también han forjado subjetividades dispuestas a negociar su territorio. Es decir, la violenta lógica de la desposesión busca reafirmar la propiedad tanto de la espacialidad como de la subjetividad, encarnando subjetividades desplazadas y desplazables, "instándolas a tomar un lugar estipulado como propio, en lugar de darse un lugar" (Butler y Athanasiou, 2017, pp. 26-27).

\section{Conclusiones}

En una ciudad que muchos temen se quedará sin agua o será tragada por inundaciones catastróficas, el crecimiento urbano y sus grandes obras de infraestructura siguen en aumento. En medio de esta incongruencia, mientras las elites impulsoras de los mega desarrollos de infraestructura, 
ya sea inmobiliarios, carreteros o aeroportuarios, no ven límites con relación al agua ni viven los impactos sociales y ecológicos de las inundaciones o los desecamientos, en las poblaciones de los márgenes no sólo se viven en carne propia los efectos de este desastre progresivo, sino que además se experimenta bajo formas múltiples de despojo.

En este contexto, a lo largo de este artículo he expuesto cómo, cuando miramos a los desastres sin tanta prisa o sin esperar su espectacularidad, el despojo y el desastre de la desecación se han dado de manera sostenida en el tiempo a través de modalidades poco menos visibles, pero igualmente violentas y ya normalizadas. En realidad, el desastre de la desecación sucede cotidianamente por debajo de los pies de quienes habitan la metrópoli; las grandes tuberías que lo hacen posible se encuentran kilómetros debajo de las casas y los grandes edificios corporativos. No obstante, la narrativa de la huida de La Sirena es signo de las formas específicas y desiguales en que se da sentido y experimenta el proceso de desecación.

Mientras que los discursos de los agentes de Estado y el capital privado reifican la desecación a partir de la idea de la resiliencia de la urbe, desde la experiencia de los pueblos del nororiente esta desecación se proyecta dramáticamente, no solo en términos ecosistémicos, sino también en las economías locales, las pertenencias territoriales e identidades colectivas. A partir de este caso, y como lo ha sugerido con anterioridad Bonilla (2020) y también Nixon (2011), me propuse llamar la atención sobre los efectos persistentes de los desastres y sus momentos de ruptura temporal. Con ello, sugiero reformular los desastres como eventos lentos y progresivos, y a su vez, desviar la atención de lo repentino, lo espectacular y las grandes escalas, hacia las realidades cotidianas y a micro escala que enfrentan las víctimas de desastres al ser afectadas y reconstruir sus vidas. De esta manera, es posible observar las formas íntimas en que los desastres y los despojos se coproducen más allá de los desplazamientos o reasentamientos forzados.

De tal manera, al ver los desastres como procesos de largo aliento y rescatar los sentidos que desde lugares concretos se le asignan, es posible ubicar variadas e insidiosas formas en que el despojo acontece. Asimismo, es posible insistir en la dimensión ecológica del despojo, más allá de sus implicaciones políticas y económicas, y apuntar cómo los desastres, engarzados a otros procesos de despojo, producen paisajes concretos que dan cuenta de la desigualdad, del sufrimiento, así como de su carácter procesual. 
Desde esta perspectiva ha sido posible sostener que el despojo puede ir más allá de la idea de la propiedad y la acumulación de capital. Cuando escuchamos a quienes encarnan los procesos de desastre y despojo, podemos sostener que la experiencia de ser despojados tiene que ver también con la pérdida de la capacidad organizativa, los sentidos de vida comunitaria y, parafraseando a Butler y Athanasiou (2017), de la capacidad de darse un lugar.

La narrativa de la huida de la Sirena no sólo remite a un pasado de bucles de despojo que nos deja sin salida, sino que conecta este tiempo pasado a un futuro perfecto a partir del cual emergen expectativas desde diversos y desiguales lugares, y desde el cual es posible imaginar otros escenarios donde es posible encontrar otros lugares. Para los más viejos pobladores de la Costa Chica texcocana la Sirena habrá regresado para cuando su lago esté de vuelta. Más que una utopía nostálgica, la narrativa evoca una pregunta provocadora ¿cuál será la transfiguración del lago a su regreso?

\section{Referencias bibliográficas}

Albores, B. A. (1995). Tules y sirenas. El impacto ecológico y cultural de la industrialización en el Alto Lerma. El Colegio Mexiquense.

Apenes, O. (1943). The "Tlateles" of Lake Texcoco. American Antiquity, 9(1), 29-32.

Aragón, F. (2007). Urbanisation and flood vulnerability in the periurban interface of Mexico City. Disasters, (31), 477-494. https://doi.org/10.1111/j.1467-7717.2007.01020.x

Aréchiga, E. (2004). El desgüe del Valle de México, siglos XVI-XXI. Una historia paradójica. Arqueología Mexicana, 12(68), 60-65.

Arias, P. (2019). Los ejidos en 1935. Diversidad espacial, recursos naturales y organización social. Sociedad y Ambiente, 7(20), 153-186. https://doi.org/10.31840/sya.v0i20.1997

Berglund, E., Lounela, A. y Kallinen, T. (2019). Landscape is not what it used to be: Anthropology and the politics of environmental change. En A. Lounela, E. Berglund y T. Kallinen (eds.), Dwelling in Political Landscapes Contemporary Anthropological Perspectives (pp. 8-32). Studia Fennica Anthropologica-Finnish Literature Society-SKS.

Bonilla, Y. (2020). The coloniality of disaster: Race, empire, and the temporal logics of emergency in Puerto Rico, USA. Political Geography, 78, 102-181.

Butler, J. y Athanasiou, A. (2017). Desposesión. Lo performativo en lo político. Eterna Cadencia Editora.

Camacho, D. (2008). Atenco arma su historia (Tesis de maestría). Universidad Autónoma Metropolitana, México.

Camargo, A. y Ojeda, D. (2017). Ambivalent desires: State formation and dispossession in the face of climate crisis. Political Geography, 60, 57-65. http://dx.doi.org/10.1016/j. polgeo.2017.04.003 
Castillo, O. (2013). Mosaicos de ciudad en el agua. Riesgo por inundación y vulnerabilidad: el caso de dos municipios del Estado de México (Tesis de Maestría). Universidad Autónoma Metropolitana-Cuajimalpa, Ciudad de México, México.

Chahim, D. (7 de julio de 2020). Self-Devouring Urbanism: Displacements of Capital and Water in Mexico City. Items, Insights from the Social Sciences. https://items.ssrc. org/layered-metropolis/self-devouring-urbanism-displacements-of-capital-andwater-in-mexico-city/

Cházaro, L. (2014). El lago de Texcoco y la ciudad de México: entre las diferencias políticas y la higiénica igualdad. En E. Ribera, H. Mendoza y M. Pere (coords.), La integración del territorio en una idea de Estado. México y Brasil, 1821-1946 (pp. 423-441). Universidad Nacional Autónoma de México, Instituto de Geografía/Instituto de Investigaciones Dr. José Luis Mora.

Cirelli, C. (1997). La transferencia de agua: el impacto en las comunidades origen del recurso. El caso de San Felipe y Santiago, Estado de México. Universidad Iberoamericana.

Cirelli, C. (2004). Agua desechada, agua aprovechada. Agricultores al margen de la ciudad. El Colegio de San Luis.

Córdova, F., Straffon, A., Ortiz, G.A., Levy, K., Arellano, O., Ayala, C., Zambrano, L., Sánchez, D.J. y Acosta, S. (2015). Análisis del resolutivo SGPA/DGIRA/DG/09965 del proyecto "Nuevo Aeropuerto Internacional de la Ciudad de México, S. A. de C. V." MIA15EM2014V0044. Grupo de Análisis de Manifestaciones de Impacto Ambiental. Unión de Científicos Comprometidos con la Sociedad.

De Alba, F. y Castillo, O. (2014). Después del desastre... viene la informalidad. Una reflexión sobre las inundaciones en la metrópolis de México. Revista de Direito da Cidade, 6(1), 141-167. https://www.raco.cat/index.php/RIURB/article/view/306818

De Alba, F. y Kloster, K. (2007a). ¿Un nuevo paradigma en los conflictos sociales? Una metrópoli en fragmentación progresiva: las luchas por el agua en la Ciudad de México. Revista Estudios Sociales Comparativos, 1(1), 7-34.

De Alba, F. y Kloster, K. (2007b). El agua en la Ciudad de México y el factor de fragmentación política. Revista Perfiles Latinoamericanos, 1(29), 137-60. https://perfilesla.flacso.edu. $\mathrm{mx} /$ index.php/perfilesla/article/view/207

Espinosa, G. (1996). El embrujo del lago. El sistema lacustre de la cuenca de México en la cosmovisión mexica. Universidad Nacional Autónoma de México, Instituto de Investigaciones Históricas, Instituto de Investigaciones Antropológicas.

Federici, S. (2010). Calibán y la bruja: mujeres, cuerpo y acumulación originaria. Traficantes de Sueños.

García R. (2002). Tetzcotzinco y alrededores, Estado de México. Arqueología Mexicana, 10(58). Gordillo, G. (2014). Rubble: The Afterlife of Destruction. Duke University Press.

Hart, G. (2016). Desnaturalizar el despojo: una etnografía crítica en la era del resurgimiento del imperialismo. Revista Colombiana de Antropología, 52(2), 139-173. https://revistas. icanh.gov.co/index.php/rca/article/view/85

Harvey, D. (2004). El nuevo imperialismo. Ediciones Akal. 
Hofmann, S. y Oliver-Smith, A. (2020). Introduction to the second edition. En S. Hofmann y A. Oliver-Smith (eds.), The angry earth: Disaster in anthropological perspective (pp. 1-15). Routledge.

Ibarra M. V. (2017). Tensiones y conflictos por agua en el boom inmobiliario de Tecámac, México. Territorios, (37), 81-99. https://doi.org/10.12804/revistas.urosario.edu.co/ territorios/a.4818

Kaika, M. (2006) City of Flows. Nature, Modernity, and the City. Routledge, Taylor \& Francis.

Kimelman, M. (17 de febrero de 2017). Ciudad de México, al borde de una crisis por el agua. New York Times. https://www.nytimes.com/interactive/2017/02/17/world/ americas/mexico-city-sinking-es.html

Li, T. (2010). Indigeneity, capitalism, and the management of dispossession. Current anthropology, 51(3), 385-414. https://www.journals.uchicago.edu/doi/abs/10.1086/651942

Mendoza, A. (2018). Ontologías del agua y relaciones de poder en torno al paisaje hídrico en el territorio indígena mazahua del estado de México. Revista Colombiana de Antropología, 55(1), 91-118. https://doi.org/10.22380/2539472X.572

Moran, J. D. (2014). Paisaje urbano y desastres. Quid 16. Revista del Área de Estudios Urbanos, (4), 186-223. https://publicaciones.sociales.uba.ar/index.php/quid16/article/view/1158

Moran, J. D. (2017). Escenarios de riesgos y desastres por sismos e inundaciones en la zona metropolitana de la Ciudad de México. El Colegio de San Luis.

Navarro, M. L. (2015). Luchas por lo común. Antagonismo social contra el despojo capitalista de los bienes naturales en México. Benemérita Universidad Autónoma de Puebla.

Nixon, R. (2011). Slow Violence and the Environmentalism of the Poor. Harvard University Press.

Ojeda, D. (2016). Los paisajes del despojo: propuestas para un análisis desde las reconfiguraciones socioespaciales. Revista Colombiana de Antropología, 52(2), 19-43. https://orcid.org/0000-0003-2009-8060

Oliver-Smith, A. (1998). Global changes and the definition of disaster. En Quarantelli E. (ed), What is a disaster? Perspectives on the question (pp. 177-194). Routledge.

Oliver-Smith, A. (ed.). (2009). Development $\mathcal{E}$ dispossession: the crisis of forced displacement and resettlement. School for Advanced Research Press.

Oliver-Smith A. (2020). What is a disaster? Anthropological perspectives on a persistent question. En S. Hofmann y A. Oliver-Smith (eds.), The angry earth: Disaster in anthropological perspective (pp. 29-40). Routledge.

Oropeza, O. (2008). Prevención de desastres de origen hidrometeorológico, una prioridad nacional: el caso de las inundaciones. En D. Rodríguez, S. Lucatello y M. Garza (coords.), Políticas públicas y desastres (pp. 125-144). Instituto Mora y Red Mexicana de Estudios Interdisciplinarios para la Prevención de Desastres.

Ortiz, C. A. y Gutiérrez, M. C. (2015). El Nuevo Aeropuerto Internacional de la Ciudad de México: Las limitaciones de los terrenos del ex lago de Texcoco. Artículos y Ensayos de Sociología Rural, 10(19), 11-23. https://doi.org/10.18046/recs.i24.2396

Parsons, J. (2006). The Last Pescadores of Chimalhuacán, Mexico: An Archaeological Ethnography. University of Michigan Museum. 
Parsons, J. y Whalen, M. (1982). Prehispanic Settlement Patterns in the Southern Valley of Mexico: The Chalco-Xochimilco Region. Museum of Anthropology/University of Michigan.

Perló-Cohen, M. (1999). El paradigma porfiriano. Historia del desagüe del Valle de México. UNAM, Instituto de Investigaciones Sociales.

Perló-Cohen, M. y González-Reynoso A. (2006). Del agua amenazante al agua amenazada. En Martínez-Fernández, Más allá del Cambio Climático: las dimensiones psicosociales del cambio ambiental global (pp. 47-64). Instituto Nacional de Ecología.

Perló-Cohen, M. y González-Reynoso, A. (2005). ¿Guerra por el agua en el Valle de México? Estudio sobre las Relaciones Hidráulicas entre el Distrito Federal y el Estado de México. National Autonomous University of Mexico, Autonomous Metropolitan University, and Friedrich Ebert Foundation.

Pineda, N. (2002). La política urbana de agua potable en México: del centralismo y los subsidios a la municipalización, la autosuficiencia y la privatización. Región y Sociedad, Revista de El Colegio de Sonora, 14(24), 41-69.

Popke, J. y Rhiney, K. (2019). Introduction to Special Issue on The Caribbean after Irma and Maria: Climate, Development \& the Post-Hurricane Context. Journal of Extreme Events, 6(1), 1-10. https://doi.org/10.1142/S2345737619020019

Quiñones, J. P. (2012). Las inundaciones en el Distrito Federal. Un ejemplo de la construcción del riesgo y la vulnerabilidad. En A. Murrieta (coord.), Espacios Tatuados: textos sobre el estudio de las regiones y los territorios (Cuadernos de trabajo de posgrado, Maestría en Estudios Regionales) (pp. 123-142). Instituto Mora.

Rhiney, K. (2019). Rethinking resilience and its ethico-political possibilities Dialogues. Human Geography, 9(2), 197-200. https://doi.org/10.1177\%2F2043820619827742

Rhiney, K. (2020). Dispossession, disaster capitalism and the post-hurricane context in the Caribbean. Political Geography, 78. http://dx.doi.org/10.1016/j.polgeo.2020.102171

Rojas-Rabiela, T. (2009). Las obras hidráulicas en las épocas prehispánica y colonial. En Comisión Nacional del Agua (comp.), Semblanza histórica del agua en México (pp. 9-25). Comisión Nacional del Agua.

Rosas Vargas, R. (2013). San Salvador Atenco. Historia agraria (1910-1940). Altres Costa/Amic Editores.

Serra Puche M. C. (1988). Los recursos lacustres de la cuenca de México durante el Formativo (Tesis de doctorado). Instituto de Investigaciones Antropológicas, Universidad Nacional Autónoma de México, México.

Soto Coloballes, N. (2019a). La ciudad que secó sus lagos y hoy enfrenta la escasez de agua. Dirección General de Divulgación de la Ciencia, UNAM. http://ciencia.unam.mx/ leer/848/la-ciudad-que-seco-sus-lagos-y-hoy-enfrenta-la-escasez-de-agua-

Soto Coloballes, N. (2019b). Proyectos y obras para el uso de los terrenos desecados del antiguo lago de Texcoco, 1912-1998. Estudios de Historia Moderna y Contemporánea de México, (58), 259-287. https://doi.org/10.22201/iih.24485004e.2019.58.70695

Sugiura, Y. (1983). Notas sobre el modo de subsistencia lacustre. La laguna de Santa Cruz Atizapán, Estado de México. Anales de Antropología, 20(1). 
Sugiura, Y. (2015). Vivir entre volcanes, bosques y agua: los antiguos isleños de santa cruz atizapán. Anales de Antropología, 49(1), 185-221. https://doi.org/10.1016/S01851225(15)71650-4

Swyngedouw, E. (1997). Power, nature, and the city. The conquest of water and the political ecology of urbanization in Guayaquil, Ecuador: 1880-1990. Environment and planning A, 29(2), 311-332.

Swyngedouw, E. (2004). Social Power and the Urbanization of Water: Flows of Power. Oxford University Press.

Taussig, M. (1993). El diablo y el fetichismo de la mercancía en Sudamérica. Editorial Nueva Imagen.

Tsing, A. (2015). The mushroom at the end of the world: On the possibility of life in capitalist ruins. Princeton University Press.

Vázquez García, V. (2018). Género y arrebato de tierras: el caso del nuevo aeropuerto internacional de Ciudad de México. Región y sociedad, 30(73). https://doi.org/ 10.22198/rys.2018.73.a979

Vázquez, V. (2020a). Género y privatización del ejido en San Salvador Atenco, México. Perfiles latinoamericanos, 28(55), 325-348. https://doi.org/10.18504/pl2855-013-2020

Vázquez, V. (2020b). Venta de tierras y transformación del waterscape en San Salvador Atenco, Estado de México. Cuicuilco, Revista de Ciencias Antropológicas, 27(77), 183-206.

Vitz, M. (2012), The lands with which we shall struggle: land reclamation, revolution, and development in Mexico's Lake Texcoco Basin, 1910-1950. Hispanic American Historical Review, 92(1), 41-71. https://doi.org/10.1215/00182168-1470968

Vitz, M. (2018). A city on a lake: Urban political ecology and the growth of Mexico City. Duke University Press.

Villarreal, A. y D. Mercier. (2010). ¿Hacia un sistema integrado de transporte urbano en el área metropolitana de Monterrey?: La figura del hombre camión. En L. Palacios (ed.), Cuando México enfrenta la globalización. Permanencias y cambios en el área metropolitana de Monterrey (pp. 457-468), Monterrey: Universidad Autónoma de Nuevo León.

Weber, M. (2003 [1905]). La ética protestante y el espíritu del capitalismo. México: Fondo de Cultura Económica.

Ziccardi, A. y González, A. (2011). Pobreza, Agua y Cambio Climático en la Ciudad de México. UNAM/PUEC/GDF/ICYTDF. 